\title{
Assessment of device-associated infection rates in teaching hospitals in Islamic Republic of Iran
}

\begin{abstract}
Shirin Afhami, ${ }^{1}$ Arash Seifi, ${ }^{2}$ Mahboubeh Hajiabdolbaghi, ${ }^{2}$ Negin Esmailpour Bazaz, ${ }^{1}$ Azar Hadadi, ${ }^{3}$ Mehrdad Hasibi, ${ }^{4}$ Parvin Rezaie, ${ }^{5}$ Esmail Mohamadnejad, ${ }^{6}$ Azam Ghahan, ${ }^{6}$ Mitra Hajinoori, ${ }^{8}$ Fatemeh Veyceh, ${ }^{7}$ Shahnaz Adinehkharrat, ${ }^{6}$ Zahraparvin Hojjati ${ }^{6}$ and Zohre Azimbeik ${ }^{7}$

${ }^{2}$ Department of Infectious Diseases, Shariati Hospital, Tehran University of Medical Sciences, Tehran, Islamic Republic of Iran. ${ }^{2}$ Department of Infectious Diseases, Imam Khomeini Hospital, Tehran University of Medical Sciences, Tehran, Islamic Republic of Iran (Correspondence to: Arash Seifi: a-seifi@sina.tums.ac.ir). ${ }^{3}$ Department of Infectious Diseases, Sina Hospital, Tehran University of Medical Sciences, Tehran, Islamic Republic of Iran. ${ }^{4}$ Department of Infectious Diseases, Amir Alam Hospital, Tehran University of Medical Sciences, Tehran, Islamic Republic of Iran. ${ }^{5}$ Department of Nursing, Shariati Hospital, Tehran University of Medical Sciences, Tehran, Islamic Republic of Iran. ${ }^{6}$ Department of Nursing, Imam Khomeini Hospital, Tehran University of Medical Sciences, Tehran, Islamic Republic of Iran. ${ }^{7}$ Department of Nursing, Sina Hospital, Tehran University of Medical Sciences, Tehran, Islamic Republic of Iran. ${ }^{8}$ Department of Nursing, Amir Alam Hospital, Tehran University of Medical Sciences , Tehran, Islamic Republic of Iran.
\end{abstract}

\begin{abstract}
Background: Surveillance of health care-associated infections (HCAIs) is an integral part of infection control programmes, especially in intensive care units (ICUs). Device-associated infections (DAIs) are a major threat to patient safety.
\end{abstract}

Aim: To measure DAI rates in ICUs.

Methods: Central line-associated bloodstream infection (CLABSI), ventilator-associated pneumonia (VAP), and catheter-associated urinary tract infection (CAUTI) were assessed in the ICUs of 4 tertiary-care teaching hospitals in Tehran, Islamic Republic of Iran.

Results: The incidence rate of CLABSI, VAP and CAUTI was 10.20, 21.08 and 7.42 per 1000 device-days, respectively. The utilization ratio for central lines, ventilators and urinary catheters was $0.62,0.47$, and 0.84 , respectively. The most common organisms were Acinetobacter (33.5\%) and Klebsiella (19.0\%). Sixty to eighty percent of Enterobacteriaceae were extended-spectrum beta-lactamase producing. About half of Pseudomonas aeruginosa isolates were resistant to piperacillin/ tazobactam and carbapenem. Acinetobacter resistance rate to ampicillin/sulbactam and carbapenem was $70-80 \%$. The prevalence of methicillin-resistant Staphylococcus aureus and vancomycin-resistant Enterococcus was 84.6\% and 83.3\%, respectively.

Conclusions: This study showed high incidence rates of DAIs and resistant organisms, and appropriate interventions are necessary to reduce these rates.

Keywords: catheter-related infections; pneumonia; urinary tract infections; drug resistance; intensive care units.

Citation: Afhami S; Seifi A;Hajiabdolbaghi M; Bazaz NE;Hadadi A; Hasibi M; et al .Assessment of device-associated infection rates in four teaching hospitals in Islamic Republic of Iran. East Mediterr Health J. 2019;25(2):90-97. https://doi.org/10.26719/emhj.18.015

Received: 12/02/16; accepted: 30/08/17

Copyright $@$ World Health Organization (WHO) 2019. Some rights reserved. This work is available under the CC BY-NC-SA 3.0 IGO license (https:// creativecommons.org/licenses/by-nc-sa/3.o/igo).

\section{Introduction}

Healthcare-associated infections (HAIs) affect patients with indwelling devices in hospitals and other healthcare facilities, and are the most common cause of increased morbidity, mortality and cost in hospitalized patients, especially in high-risk settings, such as intensive care units (ICUs) (1-4). Central line-associated bloodstream infection (CLABSI), ventilator-associated pneumonia (VAP) and catheter-associated urinary tract infection (CAUTI) are 3 major device-associated infections (DAIs). These infections pose the greatest threat to patient safety, and the standard definitions have been provided by the Centers for Disease Control and Prevention (CDC) (5).

The rate of HCAIs varies between countries, but in low- and middle-income countries, overall rates of DAIs per 1000 device-days in adult ICUs are strikingly higher than those reported in high-income countries (6-8). In the ICUs of low- and middle-income countries, the
CLABSI incidence per 1000 central line-days is $4.9-12.2$ (0.9-3.5 in high-income countries), the VAP incidence per 1000 ventilator-days is $16.8-23.9$ (1.1-7.9 in high-income countries), and the CAUTI incidence per 1000 urinary catheter-days is 5.5-8.8 (1.3-4.1 in high-income countries) $(1-4,6,7)$. In addition to the risk factors associated with HCAI in high-income countries, other risk factors have been identified in acute-care settings in low- and middleincome countries that are more broadly associated with poverty, such as a lack of basic hygiene, and limited resources. These factors include malnutrition, age $<1$ year, low birth weight, parenteral nutrition, and $\geq 2$ underlying diseases (6). Although not demonstrated as independent risk factors, general barriers to optimal infection control practices in low- and middle-income countries are lack of financial support, inadequate numbers of trained personnel working in infection control, understaffed hospital units, and insufficient equipment and supplies. In resource-constrained settings, compliance with 
standard recommendations for infection prevention and control is generally not optimal, and the capacity of existing systems to respond to the increased demand associated with HCAI, such as length of stay (LOS), cost, effective antimicrobial therapy and advanced technology is also limited (8).

Surveillance of DAIs is an important part of the infection control programme of any hospital. It defines the extent of the problem, which is the initial step toward planning strategies to ensure quality of health care and reducing threat of infection. In hospitals, information about the epidemiology of infections and antimicrobial resistance patterns of microorganisms is of utmost importance in ICUs $(1,2,8)$, and different incidences of DAIs show the importance of gathering and evaluating own-hospital data for development of appropriate infection control programmes. Surveillance data on the epidemiology of DAIs and antimicrobial resistance patterns of related microorganisms are limited in the Islamic Republic of Iran. Therefore, this study was conducted to determine the burden and antimicrobial resistance patterns of CLABSI, VAP (ventilator-associated event; VAE) and CAUTI in 15 adult ICUs of 4 tertiary care teaching hospitals in Tehran, Islamic Republic of Iran.

\section{Methods}

\section{Setting}

This observational prospective study was conducted from February to March 2014 in 15 adult medical and surgical ICUs of 4 teaching hospitals in Tehran to assess the incidence per 1000 device-days of 3 common DAIs: CLABSI, VAP and CAUTI, as defined by the CDC criteria $(3,5,9)$. This study was approved by the local Research and Ethics Committee, and the need for informed consent was waived in view of the observational nature of the study. The recorded data were coded for patient confidentiality, and only the infection control teams were informed. In all 4 hospitals there is an infection control team including an infection control nurse (with at $\geq 5$ years' experience) and an infectious diseases specialist (infection control physician with $>10$ years' experience). The hospitals also have microbiology laboratories to provide in vitro susceptibility testing of clinical isolates using standardized methods.

\section{Surveillance}

We measured DAI acquisition attributable to the ICU. Each patient admitted to 1 of the 15 ICUs who received a device (central line, mechanical ventilation or urinary catheter) was monitored prospectively for the development of DAIs on a daily basis. Infection control nurses collected data on CLABSI, VAP and CAUTI occurring in patients in each ICU using CDC data sheets for surveillance of DAIs, and infection control physicians supervised the process. Patients who did not receive a device were excluded from the study. Patients' demographic data were recorded: name, sex, date of birth, admission date, admission ward, and LOS. Device-days and patient-days were collected as denominator data, and microbiological investigations were also recorded.

\section{Definitions of DAIs}

DAIs were defined according to the CDC criteria published in January 2014 (5) (see Appendix).

\section{Culture techniques}

For CLABSI, the central line was removed aseptically, and the distal $5 \mathrm{~cm}$ of the catheter (i.e., catheter tip) was cultured using a standardized semiquantitative method. Concomitant samples for blood culture were drawn percutaneously. For VAP, in all cases, a deep tracheal aspirate from the endotracheal tube was cultured aerobically and Gram staining was performed. For CAUTI, urine samples were aseptically aspirated from the sampling port of the urinary catheter and cultured quantitatively. To identify microorganisms, standard laboratory methods were used, and susceptibility tests were performed in all cases (10).

\section{DAI rate calculation}

Device-associated incidence density was calculated by number of DAI episodes $\times 1000 /$ number of device-days. The incidence density rates of CLABSI (number of cases per 1000 central line-days), VAP (number of cases per 1000 mechanical ventilator-days) and CAUTI (number of cases per 1000 urinary catheter-days) were measured. The rates of CLABSI, VAP and CAUTI per 1000 device-days were calculated by dividing the total number of DAIs by the total number of specific device-days and multiplying the result by 1000.

Device utilization ratio was calculated by number of device-days divided by the number of patient-days. Device-days were calculated by the total number of days of exposure to the device (central line, ventilator, or urinary catheter) for all the patients in the ICUs during the study period, and patient-days were calculated by the total number of days that patients were in the ICUs during the study period.

\section{Statistical analysis}

Variables including standard demographic information (name and identifier, sex, date of birth, admission date, and admission ward), LOS, admission and discharge diagnoses, surgical/invasive procedures, device utility days (endotracheal tube, intravascular catheter, and urinary catheter), and laboratory and pharmacy data were collected. Continuous variables were presented as mean and standard deviation (SD) and categorical variables as numbers and percentages.

\section{Results}

The types of ICU and numbers of beds and patients are shown in Table 1. DAI rate and device utilization ratio are summarized in Table 1. There were 169 DAIs detected in 1545 patients: 48 episodes of CLABSI, 74 of VAP and 47 of CAUTI. The overall incidence rate per 1000 device-days of CLABSI, VAP and CAUTI was 10.20, 21.08 and 7.42, respectively. 


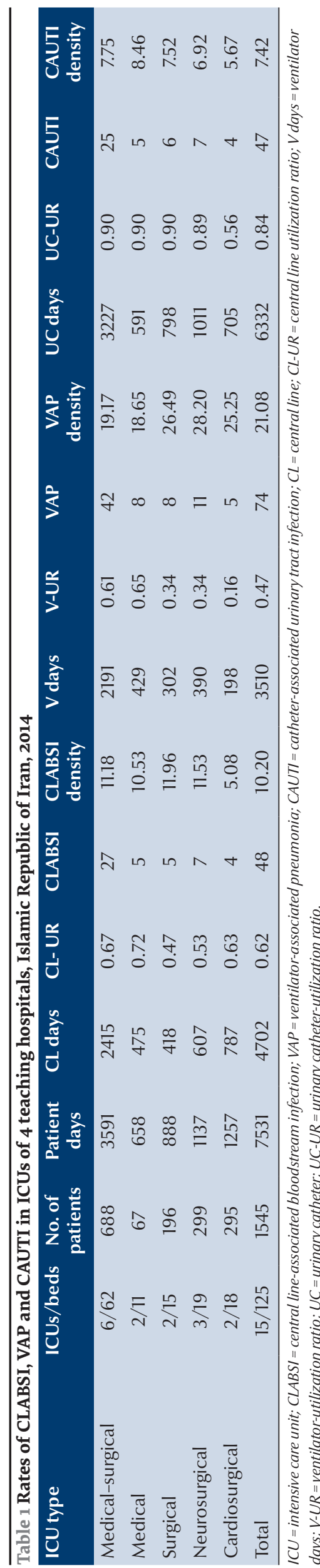

The mean (SD) duration between device insertion and infection symptom onset was 18.8 (16.4) days for CLABSI, 17.8 (15.6) days for VAP and 22.2 (17.4) days for CAUTI. The mean age of patients with DAIs was 55.3 (21.9) years; sex distribution was $58 \%$ male to $42 \%$ female; and mean LOS was 44.0 (29.4) days (Table 2). Mortality rate for CLABSI, VAP and CAUTI was $45.5 \%, 50.7 \%$ and $27.5 \%$, respectively, and $50 \%$ overall. Some patients who died experienced $>1$ infection.

The causative agents of various types of DAI are shown in Table 3 . Since $>1$ organism may cause an infection, 179 isolates were responsible for 169 episodes of DAI, and Gram-negative bacteria were the predominant isolates $(147 ; 82.1 \%)$. Twenty-nine (16.2\%) Gram-positive bacteria and $3(1.7 \%)$ fungi were also isolated. A total of 52 pathogens were isolated from blood cultures as CLABSI agents, and Acinetobacter baumannii (12; 23.1\%) and Klebsiella pneumoniae (10; 19.2\%) were the most common isolates. A. baumannii $(38 ; 48.1 \%)$ and K. pneumoniae $(14 ; 17.7 \%)$ were most frequently implicated in VAP. In CAUTI, Escherichia coli $(15 ; 31.3 \%)$ was the most prevalent among the 48 isolates detected.

The antimicrobial resistance pattern of the isolates is shown in Table 4. With the exception of colistin, $>65 \%$ of Acinetobacter strains were resistant to various antimicrobial agents: $>90 \%$ were resistant to ceftazidime and fluoroquinolones, $70-80 \%$ to aminoglycosides and ampicillin/sulbactam, and $66.7 \%$ to carbapenem. Half of Pseudomonas aeruginosa isolates were resistant to ceftazidime, piperacillin/tazobactam and carbapenem, $47.4 \%$ to aminoglycosides, and $37.9 \%$ to fluoroquinolones. Among Enterobacteriaceae isolates, $80 \%$ of E. coli and $70 \%$ of Klebsiella isolates produced extended spectrum beta-lactamase producing; resistance to fluoroquinolone was $40-70 \%$ in this group. Among Staphylococcus aureus isolates, $84.6 \%$ were methicillinresistant Staphylococcus aureus (MRSA) and $83.3 \%$ of Enterococcus isolates were vancomycin-resistant Enterococcus (VRE).

\section{INIS software}

This software is a national freeware for the surveillance of HAIs. As a part of the study, the data collected about patients with or without DAIs, as confirmed by physicians, were compared with the output of INIS software. The software identified all DAIs cases with no false-positive or false-negative results. The feedback of infection control practitioners showed that INIS software was user-friendly (http://inis.health.gov.ir).

\section{Discussion}

In the present study, we carried out prospective surveillance of 3 main DAIs (CLABSI, VAP and CAUTI) in ICUs of 4 tertiary teaching hospitals in the Islamic Republic of Iran. The incidence density for CLABSI, VAP and CAUTI per 1000 device-days was 10.20, 21.08 and 7.42, respectively. According to a World Health Organization (WHO) report, the incidence density for CLABSI, VAP and CAUTI per 1000 device-days in developed countries is 3.5, 7.9 and 4.1, respectively, compared with 12.2, 23.9 and 8.8 in developing countries (2). In the present study, the rate of DAIs in the ICUs was approximately $2-3$ times higher than that in high-income countries, but less than the rate in low- and middle-income countries. According to the International Nosocomial Infection Control Consortium (INICC) report for DAIs in 503 ICUs in low- and middle-income countries, the incidence density for CLABSI, VAP and CAUTI per 1000 device-days was 4.78, 14.7 and 5.30, respectively (3); these infections were higher in the present study. According to the National Healthcare Safety Network (NHSN) annual report for 2012, even in high-risk ICUs in the United States of America, the rate for CLABSI, VAP and CAUTI per 1000 device-days was only 3.4, 4.4 and 5.0, respectively (4). Possible reasons for the higher rates in the Islamic Republic of Iran include: low compliance with hand hygiene; lack of proper training and deficiency in continuous supervision; no strict control of antibiotic therapy; some limitations for isolation (e.g., absence of private rooms in most ICUs); and insufficient numbers of nurses to implement proper cohorting of staff and patients. 


\begin{tabular}{lccc}
\hline Table 2 Age, sex and LOS of patients with DAIs in ICUs of $\mathbf{4}$ teaching hospitals, Islamic Republic of Iran, 2014 \\
DAI & Mean age (SD) years & Sex, M/F (\%) & Mean LOS (SD) days \\
CLABSI & $56.9(22.3)$ & $26 / 22(54 / 46)$ & $43.2(33.2)$ \\
VAP & $57.1(20.7)$ & $47 / 27(63 / 37)$ & $42.4(26.2)$ \\
CAUTI & $50.9(22.8)$ & $25 / 22(53 / 47)$ & $47.1(29.8)$ \\
Total & $55.3(21.9)$ & $98 / 71(58 / 42)$ & $44.0(29.4)$ \\
\hline
\end{tabular}

$L O S=$ length of stay; $D A I=$ device-associated infection; $I C U=$ intensive care unit; $C L A B S I=$ central line-associated bloodstream infection; $V A P=$ ventilator-associated pneumonia; $C A U T I=$ catheter-associated urinary tract infection.

\begin{tabular}{|c|c|c|c|c|c|c|}
\hline & & Microorganism & $\begin{array}{l}\text { CLABSI } \\
\text { No. (\%) }\end{array}$ & $\begin{array}{c}\text { VAP } \\
\text { No. (\%) }\end{array}$ & $\begin{array}{l}\text { CAUTI } \\
\text { No. (\%) }\end{array}$ & $\begin{array}{c}\text { Total } \\
\text { No. (\%) }\end{array}$ \\
\hline \multirow[t]{4}{*}{ Gram positive } & \multirow{12}{*}{ 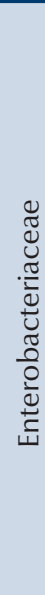 } & Staphylococcus aureus & $4(7.7)$ & $9(11.4)$ & - & $13(7.3)$ \\
\hline & & Staphylococcus epidermidis & $2(3.8)$ & - & - & $2(1.1)$ \\
\hline & & Enterococcus spp. & $8(15.4)$ & - & $4(8.3)$ & $12(6.7)$ \\
\hline & & Streptococcus spp. & $1(1.9)$ & $1(1.3)$ & - & $2(1.1)$ \\
\hline \multirow[t]{9}{*}{ Gram negative } & & Klebsiella pneumoniae & $10(19.2)$ & $14(17.7)$ & $10(20.8)$ & $34(19.0)$ \\
\hline & & Escherichia coli & $1(1.9)$ & $5(6.3)$ & $15(31.3)$ & $21(11.7)$ \\
\hline & & Proteus mirabilis & - & $2(3.5)$ & $2(4.2)$ & $4(2.2)$ \\
\hline & & Enterobacter spp. & $3(5.8)$ & - & $3(6.3)$ & $6(3.4)$ \\
\hline & & Citrobacter spp. & - & $1(1.3)$ & - & $1(0.6)$ \\
\hline & & Serratia marcescens & & $1(1.3)$ & - & $1(0.6)$ \\
\hline & & Pseudomonas aeruginosa & $8(15.4)$ & $8(10.1)$ & $3(6.3)$ & $19(10.6)$ \\
\hline & & Acinetobacter baumannii & $12(23.1)$ & $38(48.1)$ & $10(20.8)$ & $60(33.5)$ \\
\hline & & Stenotrophomonas maltophilia & $1(1.9)$ & - & - & $1(0.6)$ \\
\hline \multirow[t]{2}{*}{ Fungi } & & Candida spp. & $2(3.8)$ & - & $1(2.1)$ & $3(1.7)$ \\
\hline & & Total & $52(100)$ & $79(100)$ & $48(100)$ & $179(100)$ \\
\hline
\end{tabular}

$D A I=$ device-associated infection; $I C U=$ intensive care unit; $C L A B S I=$ central line-associated bloodstream infection; $V A P=v e n t i l a t o r$-associated pneumonia $; C A U T I=$ catheter-associated urinary tract infection.

Published surveillance data from other low- and middle-income countries have shown a wide range of results that makes any comparison and discussion difficult. Studies conducted in Argentina (CLABSI 30.3, VAP 46.3 and CAUTI 18.5 per 1000 device-days) (11) and India (VAP 30.67) (12) showed higher incidence density than in the present study. In contrast, other studies showed a lower incidence density; for example, in Brazil (CLABSI 6.4) (13) or Saudi Arabia (VAP 16.8) (14). In another study from India (15), incidence density for CLABSI, VAP and CAUTI was 13.50, 6.15 and 10.75, respectively, which, compared with the present study, showed higher incidence of CLABSI and CAUTI and lower incidence of VAP. However, yet another study from India (16) showed a higher VAP rate (21.92 per 1000 device-days) but lower CLABSI (0.48 per 1000 device-days) and CAUTI (o.6 per 1000 device-days) rate than in the present study.

In most surveillance studies conducted in the Islamic Republic of Iran, variables such as device utilization ratio, device days, patient days and incidence density have not been calculated. Instead, only the percentage of infected patients has been reported, which makes any comparison inapplicable. However, 2 studies conducted by Afhami et al. on CLABSI and VAP showed incidence density rates of 1.98 per 1000 catheter-days for CLABSI and 9.96 per 1000 ventilator days for $\operatorname{VAP}(17,18)$, which were lower than in the present study. Different incidences of DAIs may depend on the definition, type of hospital or ICU, type of patients admitted, infection control programmes of the institution, and antibiotic prescription policy.

In the present study, the utilization ratio for central lines, ventilators and urinary catheters was $0.62,0.47$ and 0.84 , respectively. According to an INICC report, the utilization ratio for central lines, ventilators and urinary catheters was $0.53,0.38$ and 0.62 , respectively (3). In an NHSN report, the utilization ratio for central lines, ventilators and urinary catheters was $0.57,0.37$ and 0.70 , respectively (4). In comparison with these data, the overall device utilization ratio was $10-20 \%$ higher in Iranian ICUs. One reason for the differences might be the type of patients admitted to the ICUs because the hospitals in our study were tertiary-level referral hospitals and most patients had serious comorbidity, and more device utilization was needed to care for such patients.

In the present study, the mean age of patients with DAIs was around 55 years; there were more men than 


\begin{tabular}{|c|c|c|c|c|}
\hline Organism & No. of isolates & Antibiotic & No. of antibiograms & $\begin{array}{c}\text { No. of resistant } \\
\text { bacteria (\%) }\end{array}$ \\
\hline \multirow[t]{3}{*}{ Staphylococcus aureus } & 13 & $\begin{array}{l}\text { Oxacillin or } \\
\text { cefoxitina }\end{array}$ & 13 & $11(84.6)$ \\
\hline & & Clindamycin & 13 & $11(84.6)$ \\
\hline & & Vancomycin & 13 & $0(0)$ \\
\hline \multirow[t]{3}{*}{ Enterococcus spp. } & 12 & Ampicillin & 9 & $6(66.7)$ \\
\hline & & Vancomycinb & 12 & $10(83.3)$ \\
\hline & & Linezolid & 6 & $0(0)$ \\
\hline \multirow[t]{4}{*}{ Klebsiella pneumoniae } & 34 & Cephalosporinc & 34 & $24(70.6)$ \\
\hline & & Fluoroquinolone & 34 & $17(50.0)$ \\
\hline & & $\begin{array}{l}\text { Beta-lactamase } \\
\text { inhibitor }\end{array}$ & 16 & $11(68.8)$ \\
\hline & & Carbapenemd & 29 & $13(44.8)$ \\
\hline \multirow[t]{4}{*}{ Escherichia coli } & 21 & Cephalosporin & 21 & $17(81.0)$ \\
\hline & & Fluoroquinolone & 21 & $14(66.7)$ \\
\hline & & $\begin{array}{l}\text { Beta-lactamase } \\
\text { inhibitor }\end{array}$ & 8 & $2(25.0)$ \\
\hline & & Carbapenemd & 17 & $1(5.9)$ \\
\hline \multirow{4}{*}{$\begin{array}{l}\text { Other fermentative } \\
\text { Enterobacteriaceae5 }\end{array}$} & 12 & Cephalosporin & 12 & $7(58.3)$ \\
\hline & & Fluoroquinolone & 12 & $5(42.0)$ \\
\hline & & $\begin{array}{l}\text { Beta-lactamase } \\
\text { inhibitor }\end{array}$ & 6 & $2(33.3)$ \\
\hline & & Carbapenemd & 11 & $2(18.2)$ \\
\hline \multirow[t]{5}{*}{ Pseudomonas aeruginosa } & 19 & Ceftazidime & 13 & $7(53.8)$ \\
\hline & & Fluoroquinolone & 19 & $11(37.9)$ \\
\hline & & Aminoglycoside & 19 & $9(47.4)$ \\
\hline & & $\begin{array}{l}\text { Piperacillin/ } \\
\text { tazobactam }\end{array}$ & 6 & $3(50.0)$ \\
\hline & & Carbapenemd & 18 & $9(50.0)$ \\
\hline \multirow[t]{6}{*}{ Acinetobacter baumannii } & 60 & Ceftazidime & 41 & $40(97.6)$ \\
\hline & & Fluoroquinolone & 45 & 41 (91.1) \\
\hline & & Aminoglycoside & 59 & $47(79.7)$ \\
\hline & & $\begin{array}{l}\text { Ampicillin/ } \\
\text { sulbactam }\end{array}$ & 37 & $29(78.4)$ \\
\hline & & Carbapenemd & 60 & $40(66.7)$ \\
\hline & & Colistind & 8 & $2(25.0)$ \\
\hline
\end{tabular}

${ }^{a}$ Indicates methicillin-resistant S. aureus; ${ }^{b}$ indicates vancomycin-resistant Enterococcus; ${ }^{c}$ third-generation cephalosporins; ${ }^{2}$ agar disc diffusion method; ${ }^{5}$ other Enterobacteriaceae: Proteus, Enterobacter, Citrobacter, Serratia. ICU = intensive care unit; DAI= device-associated infection.

women; mean LOS was > 1 month; and half of patients eventually died. In the INICC report, mean LOS was 20 days (CLABSI 19.47 days, VAP 19.66 days and CAUTI 20.99 days) and mortality was $\sim 21 \%$ (CLABSI $24.9 \%$, VAP $23.4 \%$ and CAUTI $13.3 \%$ ) (3). These data indicate that LOS and mortality of infected patients are higher in Iranian ICUs. In other reports about LOS or mortality, especially in low- and middle-income countries, the rate was similar to ours or even higher (2,14-19).

The organisms isolated in the present study were commonly Gram-negative Enterobacteriaceae, and similar findings were observed by other investigators $(1-4,6,15,16,18)$. According to the WHO, the most common organisms in ICU-acquired infections are Enterobacteriaceae (20\%), S. aureus (20\%), Pseudomonas spp. (17\%), Enterococcus spp. (10\%) and Acinetobacter spp. (5\%) (2). We found similar types of organisms but with a lower rate of S. aureus and higher rate of Acinetobacter spp. In a review of microbiological patterns of HAIs in low- and middleincome countries, the most common pathogens for BSI were S. aureus, Acinetobacter and Enterobacteriaceae; the most common pathogens for VAP were Pseudomonas, Acinetobacter and Enterobacteriaceae; the most common pathogens for UTI were Enterobacteriaceae, Pseudomonas and Acinetobacter; and the rate of MRSA was 54.5\% (6). In the present study, the same organisms were detected but there was a higher rate of MRSA (84.6\%). In the Islamic Republic of Iran, studies about UTI and VAP pathogens showed the same pattern with a predominance of Gramnegative bacteria $(15,20)$.

In Table 5 the resistance patterns of organisms isolated in the present study is compared with those reported by INICC and NHSN $(3,4)$. The organisms isolated in the present study were more antibiotic resistant than in the INICC study, except for fluoroquinolone resistance of Pseudomonas and carbapenem resistance of Acinetobacter and E. coli. In comparison with NHSN report, in our study the resistance rates of organisms for all main antibiotics were higher. 


\begin{tabular}{|c|c|c|c|c|}
\hline Organism & Antibiotic & $\begin{array}{c}\text { Resistance in present } \\
\text { study }(\%)\end{array}$ & $\begin{array}{c}\text { Resistance in INICC } \\
\text { study (\%) }\end{array}$ & $\begin{array}{c}\text { Resistance in NHSN } \\
\text { study (\%) }\end{array}$ \\
\hline Staphylococcus aureus & Oxacillin or cefoxitin & 84.6 & 53.2 & 54.6 \\
\hline Enterococcus spp. & Vancomycin & 83.3 & $9.4 \mathrm{a}$ & $9.5 \mathrm{a}$ \\
\hline \multirow[t]{4}{*}{ Pseudomonas aeruginosa } & Fluoroquinolones & 37.9 & 42.9 & 30.5 \\
\hline & Piperacillin/tazobactam & 50.0 & $36.3 b$ & $17.4 b$ \\
\hline & Aminoglycosides & 47.4 & $40.9 c$ & $10.0 \mathrm{c}$ \\
\hline & $\begin{array}{l}\text { Imipenem or } \\
\text { meropenem }\end{array}$ & 50.0 & 39.6 & 26.1 \\
\hline \multirow[t]{2}{*}{ Klebsiella pneumoniae } & $\begin{array}{l}\text { Ceftriaxone or } \\
\text { ceftazidime }\end{array}$ & 70.6 & 67.4 & 28.8 \\
\hline & $\begin{array}{l}\text { Imipenem or } \\
\text { meropenem }\end{array}$ & 44.8 & 16.9 & 12.8 \\
\hline Acinetobacter baumannii & $\begin{array}{l}\text { Imipenem or } \\
\text { meropenem }\end{array}$ & 66.7 & 70.4 & 62.6 \\
\hline \multirow[t]{3}{*}{ Escherichia coli } & $\begin{array}{l}\text { Ceftriaxone or } \\
\text { ceftazidime }\end{array}$ & 81 & 63.5 & 19.0 \\
\hline & $\begin{array}{l}\text { Imipenem or } \\
\text { meropenem }\end{array}$ & 5.9 & 7.0 & 1.9 \\
\hline & Fluoroquinolones & 66.7 & 67.9 & 41.8 \\
\hline
\end{tabular}

${ }^{a}$ Only for Enterococcus faecalis; ${ }^{b}$ resistance to piperacillin \pm tazobactam; ${ }^{c}$ resistance to amikacin. ICU = intensive care unit; INICC = International Nosocomial Infection Control Consortium; NHSN = National Healthcare Safety Network.

There were some limitations to this study. First, we collected only data about DAIs in ICUs and no other HCAIs (e.g., surgical site infections) or infections in other wards. Second, the hospitals in the present study were in a tertiary-care teaching setting; therefore, the patients with severe underlying diseases managed in these hospitals required more invasive procedures and more intensive care, so the infection rate in the present study may have been higher than the overall rate in the country.

\section{Conclusion}

This study documents a high incidence rate of DAIs and high frequency of resistant organisms in the ICUs. Effective strategies to control antibiotic-resistant bacteria should be implemented and rational use of antibiotics as prophylaxis and adherence to infection control practices are necessary to reduce these infections.

\section{Acknowledgements}

The authors would like to extend their appreciation to the ICU nurses and other personnel.

Funding: This research was supported by Tehran University of Medical Sciences and Health Services grant (grant number 25024-30-02-93).

Competing interests: None declared.

\section{Évaluation des taux d'infections associées aux dispositifs médicaux dans les hôpitaux universitaires en République islamique d'Iran}

\section{Résumé}

Contexte : La surveillance des infections associées aux soins de santé fait partie intégrante du programme de lutte antiinfectieuse, en particulier dans les unités de soins intensifs (USI).

Objectifs : Mesurer le taux d'IADM dans les USI.

Méthodes : La survenue des infections liées aux cathéters veineux centraux, des pneumonies acquises sous ventilation mécanique et des infections des voies urinaires associées aux cathéters a été évaluée dans les USI de quatre hôpitaux universitaires de soins tertiaires de Téhéran (République islamique d'Iran).

Résultats: Le taux d'incidence des infections liées aux cathéters veineux centraux, des pneumonies acquises sous ventilation mécanique et des infections des voies urinaires associées aux cathéters était de 10,20,21,08, et 7,42 pour 1000 dispositifs/jour, respectivement. Le rapport d'utilisation associé aux cathéters veineux centraux, à la ventilation mécanique et aux cathéters urinaires était de $0,62,0,47$ et 0,84 , respectivement. Les organismes les plus fréquemment retrouvés étaient Acinetobacter (33,5\%) et Klebsiella (19,0\%). Environ 60 à $80 \%$ des Enterobacteriaceae appartenaient à des souches produisant des bêtalactamases à large spectre $\left(\mathrm{ESBL}^{+}\right)$. Près de la moitié des isolats de Pseudomonas aeruginosa étaient résistants à la pipéracilline/tazobactame et aux carbapénèmes. En outre, le taux de résistance d'Acinetobacter à 
l'ampicilline/sulbactame et aux carbapénèmes était de 70 à $80 \%$. Enfin, la prévalence de Staphylococcus aureus résistant à la méticilline et d'Enterococcus résistant à la vancomycine était de 84,6\% et 83,3\%, respectivement.

Conclusions : La présente étude a montré un fort taux de prévalence des IADM et des organismes résistants dont la réduction nécessite la prise de mesures appropriées.

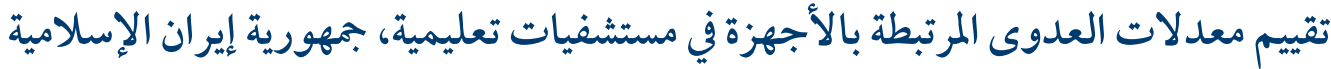

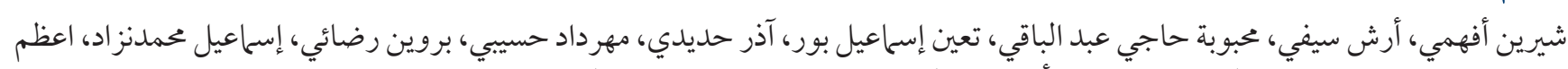

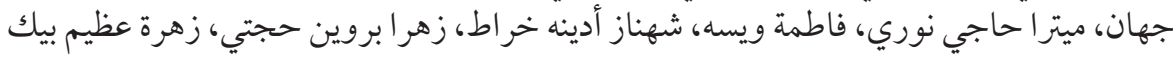

الخلاصة

الخلفية: يُعَلُّ ترصُّد حالات العدوى المرتبطة بالرعاية الصحية جزءًا لا يتجزأ من برنامج مكافحة العدوى، لا سيّما في وحدات العناية المركزة.

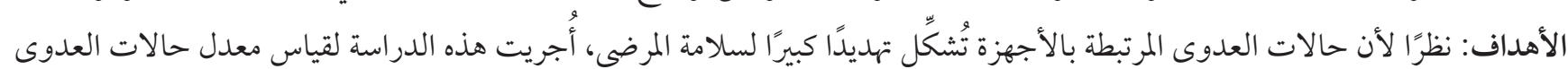
المرتبطة بالأجهزة في وحدات نطرات العناية المركزة.

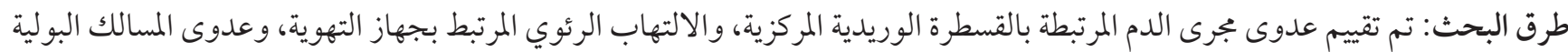

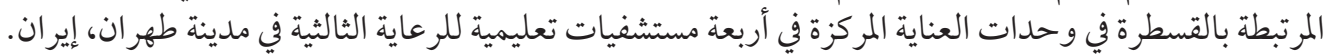

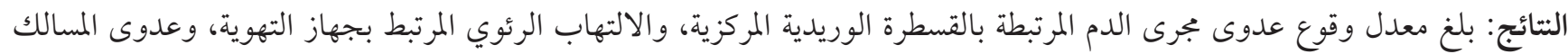

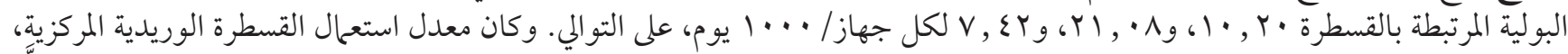

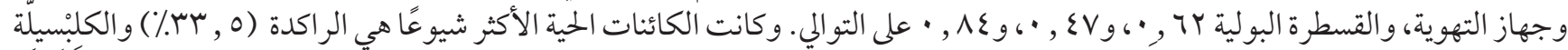

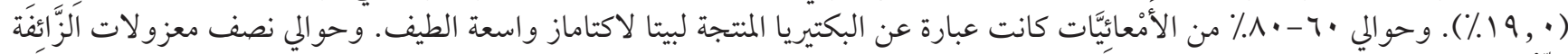

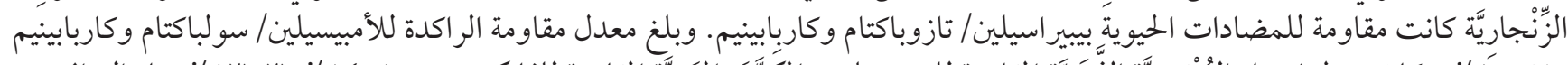

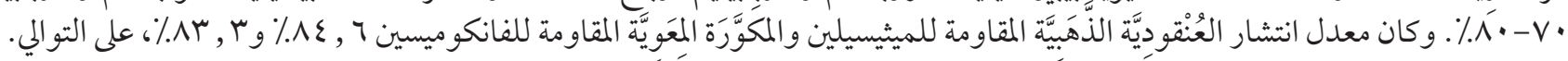

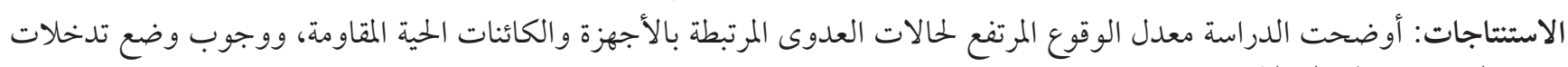
مناسبة لتخفيض هذه المعدلات.

\section{Appendix}

\section{A. Definitions of DAls according to CDC criteria 2014:}

A.1. CLABSI definition. Central line was in place for $>2$ calendar days (the central line was in place on the date of BSI or the day before); and patient has a recognized pathogen cultured from $\geq 1$ blood cultures and organism cultured from blood is not related to an infection at another site; OR patient has $\geq 1$ of these signs or symptoms (fever $>38^{\circ} \mathrm{C}$, chills, or hypotension) not related to an infection at another site and the same common commensal is cultured from $\geq 2$ blood cultures drawn on separate occasions.

A.2. VAP definition. Pneumonia was identified using a combination of radiological, clinical and laboratory criteria: the presence of a new or progressive and persistent infiltrate, consolidation, or cavitation on chest X-ray after mechanical ventilation, and $\geq 2$ of the following: temperature $>38^{\circ} \mathrm{C}$ or $<36^{\circ} \mathrm{C}$; leukocytosis: leukocyte count $>11000 / \mathrm{mm} 3$, or leukopenia < $4000 / \mathrm{mm} 3$; purulent endotracheal secretions; isolation of pathogenic bacteria from endotracheal aspiration/blood/ pleural fluid; and increasing oxygen requirements.

VAP was defined as a pneumonia in which the patient was on mechanical ventilation for $>2$ calendar days on the date of the event, with day of ventilator placement being Day 1, and the ventilator was in place on the date of the event or day before [date of event (infection date): for VAP the date of event was the date when the last element was used to meet the pneumonia criteria occurred].

VAE definition: There are 3 definition tiers within the VAE algorithm: (1) ventilator-associated condition (VAC); (2) infectionrelated ventilator-associated complication (IVAC); and (3) possible and probable VAP. VAC: Patient who had $\geq 2$ days of stability on the ventilator, began worsening oxygenation (increase in $\mathrm{FiO} 2$ of $\geq 0.20$ (20 points) or positive end-expiratory pressure of $\geq$ $3 \mathrm{cmH} 2 \mathrm{O}$ ) that sustained for 2 days; IVAC: VAC and temperature $>38^{\circ} \mathrm{C}$ or $<36^{\circ} \mathrm{C}$, OR white blood cell count $\geq 12000$ cells/ $\mathrm{mm} 3$ or $\leq 4000$ cells $/ \mathrm{mm} 3$; and a new antimicrobial agent is started and continued for $\geq 4$ calendar days. Possible/probableVAP: IVAC and purulent respiratory secretions and/or positive culture (of sputum, endotracheal aspirate, bronchoalveolar lavage, lung tissue, protected specimen brushing, or pleural fluid); OR positive lung histopathology, positive diagnostic test for Legionella spp., or positive diagnostic test on respiratory secretions for specific respiratory viruses.

A.3. CAUTI definition. Patient had an indwelling urinary catheter in place for $>2$ days (catheter was in place on the date of urinary infection or the day before); and $\geq 1$ of these signs or symptoms (fever $>38^{\circ} \mathrm{C}$, urgency, frequency, dysuria, suprapubic tenderness, costovertebral angle pain or tenderness) and a positive urine culture of $\geq 105$ colony-forming units $(\mathrm{CFU}) / \mathrm{ml}$ with no more than 2 species of microorganisms. OR above signs or symptoms and $\geq 1$ of these findings (positive dipstick for leukocyte esterase and/or nitrite; pyuria; microorganisms seen on Gram's stain of unspun urine) and a positive urine culture of $\geq 103$ and $<105 \mathrm{CFU} / \mathrm{ml}$ with no more than 2 species of microorganisms. OR without any urinary signs or symptoms but the urine culture and blood culture both were positive with the same uropathogen. 


\section{References}

1. Edmond MB, Wenzel RP, Beekmann SE. Henderson DK, Klompas M, Hooton T. Nosocomial infections. In: Bennett J, Dolin R, Blaster MJ, editors. Mandell, Douglas, and Bennett's Principles and Practice of Infectious Diseases. 8th ed. Philadelphia: Elsevier; 2015;3286-346.

2. Report on the Burden of Endemic Health Care-Associated Infection Worldwide. Geneva: World Health Organization; 2011 (http:// apps.who.int/iris/bitstream/10665/80135/1/9789241501507_eng.pdf?ua=1, accessed 6 February 2019).

3. Rosenthal VD, Maki DG, Mehta Y, Leblebicioglu H, Memish ZA, Al-Mousa HH, et al. International Nosocomial Infection Control Consortium (INICC) report, data summary of 43 countries for 2007-2012. Device-associated module. Am J Infect Control. 2014 Sep;42(9):942-56. http://dx.doi.org/10.1016/j.ajic.2014.05.029 PMID:25179325

4. Dudeck MA, Weiner LM, Allen-Bridson K, Malpiedi PJ, Peterson KD, Pollock DA, et al. National Health care Safety Network (NHSN) Report, data summary for 2012, device-associated module. Am J Infect Control. 2013 Dec;41(12):1148-66. http://dx.doi. org/10.1016/j.ajic.2013.09.002 PMID:25179325

5. $\quad \mathrm{CDC} / \mathrm{NHSN}$ surveillance definitions for specific types of infections. Atlanta: Centers for Disease Control and Prevention; 2014 (http://www.cdc.gov/nhsn/pdfs/pscmanual/17pscnosinfdef_current.pdf, accessed 6 February 2019).

6. Allegranzi B, Nejad SB, Combescure C, Graafmans W, Attar H, Donaldson L, et al. Burden of endemic health-care-associated infection in developing countries: systematic review and meta-analysis. Lancet. 2011 Jan 15;377(9761):228-41. http://dx.doi. org/10.1016/S0140-6736(10)61458-4 PMID:21146207

7. 2011 National and state health care-associated infection standardized infection ratio report. Atlanta: Centers for Disease Control and Prevention; 2013 (https://www.cdc.gov/hai/pdfs/SIR/SIR-Report_02_07_2013.pdf, accessed 6 February 2019).

8. Pittet D, Mathai E, Allegranzi B, Kilpatrick C. Prevention and control of health care-associated infections through improved hand hygiene. Indian J Med Microbiol. 2010 Apr-Jun;28(2):100-6. http://dx.doi.org/10.4103/0255-0857.62483 PMID:20404452

9. Rosenthal VD, Maki DG, Graves N. The International Nosocomial Infection Control Consortium (INICC): goals and objectives, description of surveillance methods, and operational activities. Am J Infect Control. 2008 Nov;36(9):e1-12. http://dx.doi. org/10.1016/j.ajic.2008.06.003 PMID:18992646

10. Performance standards for antimicrobial susceptibility testing; twenty-fourth informational supplement. CLSI document M100-S24. Wayne (PA): Clinical and Laboratory Standards Institute; 2014.

11. Rosenthal VD, Guzman S, Crnich C. Device-associated nosocomial infection rates in intensive care units of Argentina. Infect Control Hosp Epidemiol. 2004 Mar;25(3):251-5. http://dx.doi.org/10.1086/502386 PMID:15061418

12. Joseph NM, Sistla S, Dutta TK, Badhe AS, Parija SC. Ventilator-associated pneumonia in a tertiary care hospital in India: incidence and risk factors. J Infect Dev Ctries. 2009 Dec 15;3(10):771-7. http://dx.doi.org/10.3855/jidc.396 PMID:20009278

13. Mesiano ER, Merchan-Hamann E. Bloodstream infections among patients using central venous catheter in intensive care units. Rev Lat Am Enfermagem. 2007 May-Jun;15(3):453-9. http://dx.doi.org/10.1590/So104-11692007000300014 PMID:17653429

14. Memish ZA, Cunningham G, Oni GA, Djazmati W. The incidence and risk factors of ventilator-associated pneumonia in a Riyadh hospital. Infect Control Hosp Epidemiol. 2000 Apr;21(04):271-3. http://dx.doi.org/10.1086/501758 PMID:10782591

15. Datta P, Rani H, Chauhan R, Gombar S, Chander J. Health-care-associated infections: Risk factors and epidemiology from an intensive care unit in Northern India. Indian J Anaesth. 2014 Jan;58(1):30-5. http://dx.doi.org/10.4103/0019-5049.126785 PMID:24700896

16. Singh S, Pandya Y, Patel R, Paliwal M, Wilson A, Trivedi S. Surveillance of device-associated infections at a teaching hospital in rural Gujarat - India. Indian J Med Microbiol. 2010 Oct-Dec;28(4):342-7. http://dx.doi.org/10.4103/0255-0857.71830 PMID:20966566

17. Afhami Sh, Hadadi A. HasanNia Z, Seifi A, Esmailpour B. Catheter-related bloodstream infection and implementing Iran Nosocomial Infections Surveillance Software. J Iran Society Anaesthesiol Intensive Care. 2012;75(2):5-17 (in Farsi).

18. Afhami Sh, Hadadi A, Khorami E, Seifi A, Bazaz NE. Ventilator-associated pneumonia in a teaching hospital in Tehran and use of the Iranian Nosocomial Infections Surveillance software. East Mediterr Health J. 2013 Oct;19(10):883-7. http://dx.doi. org/10.26719/2013.19.10.883 PMID:24313153

19. Chastre J, Fagon JY. Ventilator-associated pneumonia. Am J Respir Crit Care Med. 2002 Apr 1;165(7):867-903. http://dx.doi. org/10.1164/ajrccm.165.7.2105078 PMID:11934711

20. Sadeghzadeh $\mathrm{V}$, Hasani N. The frequency rate of nosocomial urinary tract infection in intensive care unit patients in Shafiieh Hospital, Zanjan, 2004. ZUMS J. 2005;13(50):28-35. http://zums.ac.ir/journal/browse.php?a_id=365\&sid=1\&slc_lang=en 